Original Article

\title{
Nests of "caba-leão" wasps (Sceliphron sp., Sphecidae) used in traditional medicine by riverine communities of the Jaú and Unini Rivers, Amazon, Brazil: ethnopharmacological, chemical and mineralogical aspects
}

\author{
Eliana Rodrigues ${ }^{\mathrm{a}, \mathrm{b}}$, João H.G. Lago ${ }^{\mathrm{c}}$, Juliana de F.L. Santos ${ }^{\mathrm{d}}$, Ana Luisa V. Bitencourt ${ }^{\mathrm{a}, \mathrm{b}, *}$ \\ a Instituto de Ciências Ambientais, Químicas e Farmacêuticas, Universidade Federal de São Paulo, Diadema, SP, Brazil

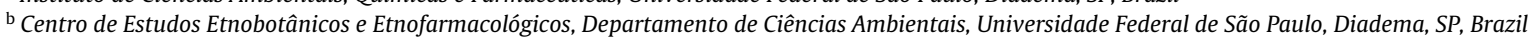

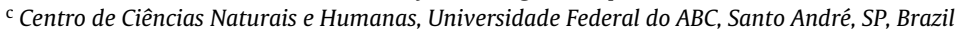 \\ ' Centro de Ciências Exatas e Tecnologia, Universidade Federal do Maranhão, São Luís, MA, Brazil
}

\section{A R T I C L E I N F O}

\section{Article history:}

Received 17 July 2017

Accepted 25 April 2018

Available online 8 May 2018

\section{Keywords:}

Ethnopharmacology

Home remedies

Insect products

Silicate minerals

\begin{abstract}
A B S T R A C T
This research contributes to the study of substances present in homemade remedies used by the riverine communities of the Amazon, which are the result of insect-mineral-vegetable oil-interaction. The results of the analyses show the main components (inorganic and organic components) of the "caba-leão" wasps nests (Sceliphron sp., Sphecidae) used by "caboclos" as a topical medication to treat mumps and earaches. The ethnopharmacological data collection consisted of samples of wasps nests and soil, as a source of inorganic elements, from the Jaú and Unini Rivers, in the River Negro basin, Amazon, Brazil. The samples were qualitatively analyzed by infrared spectroscopy (organic and inorganic composition) as well as by X-ray diffraction (to identify minerals). Quantitative chemical analyses for ten major common elements were determined by X-ray fluorescence. The inorganic components are formed by minerals (quartz, kaolinite, illite and gibbsite), identified by X-ray diffraction and Infrared spectroscopy, which are common in the soil of the region. The analyses by X-ray fluorescence indicate that the most common oxides are $\mathrm{SiO}_{2}, \mathrm{Al}_{2} \mathrm{O}_{3}$, and $\mathrm{Fe}_{2} \mathrm{O}_{3}$ within minerals. This research contributed to the study of substances found in homemade remedies used by the riverine communities of the Amazon, which are the result of insect-mineral-vegetable oil-interaction.
\end{abstract}

(c) 2018 Sociedade Brasileira de Farmacognosia. Published by Elsevier Editora Ltda. This is an open access article under the CC BY-NC-ND license (http://creativecommons.org/licenses/by-nc-nd/4.0/).

\section{Introduction}

Most ethnopharmacological studies have been dedicated to the registration of various plant species during field work and to descriptions of lists, materials and preparations of medicinal herbs. In addition, several studies have provided lists of animals and their derived products as therapeutic agents and their potential applications in traditional medicine (Adeola, 1992; Anageletti et al., 1992; Lev and Amar, 2000; Pieroni et al., 2002; Pieroni et al., 2005; Lev, 2003; Mati and de Boer, 2011; Ritter et al., 2012; Rigat et al., 2013; Antonio et al., 2013). Some authors have emphasized the medicinal use of these elements from the perspective of historical literature, demonstrating the importance of these reports to ethnopharmacology (Kujundžić et al., 2008; Liu et al., 2011). In a review of new drugs

\footnotetext{
* Corresponding author.

E-mail: ana.bitencourt@unifesp.br (A.L. Bitencourt).
}

from natural products, Harvey (2008) reported 24 drugs based on animals and 108 based on plants, which suggests that animals are still poorly studied. Moreover, many pharmacological studies of animals did not report use of ethnographic information (Mayer and Gustafson, 2003).

The medicinal use of insects and derived products is an ancient practice recorded by several authors (Cheesman and Brown, 1999; Costa-Neto, 2002). Their uses can be varied, for example, in nature, they can be cooked as well as used in infusions, in plasters or ointments for curative and preventive medicines, e.g., honey and propolis, which are products derived from Apis mellifera. Several studies have confirmed their antiseptic, anticancer and anti-HIV effects (Calderon Espina, 1989; Fernandes-Silva et al., 2014; Lopez et al., 2015). Immunological, analgesic, anaesthetic and antirheumatic proprieties have been described, and the presence of various substances, such as proteins, terpenoids, sugar, polyols, saponins, glycosides, cyanogenic glycosides and alkaloids, have been confirmed by several authors according to Alves and Rosa 
(2013). Costa-Neto (2002) reported that, in Brazil, insects have been used in healing for millennia by native indigenous populations and more recently, in the last five centuries, by descendants of Europeans and African slaves. The same author reported on thirteen Brazilian states, covering different regions South, Southeast, Midwest, North and Northeast - with records of approximately 48 ethnospecies of insects and their uses, including such wasps as the "mud wasp" (Sphecidae) and the "paper wasp" (Protopolybia exigua exigua, Brachygastra lechiguana, Polybia sericea and Apoica pallens). The author explained that bathing with the smoke from a burning nest of Protopolybia exigua exigua prevents the "evil eye". The smoke from burning of the Polybia sericea nest is used to treat "had stroke" (air sickness), and the nests of Apoica pallens, which are cooked in water and then consumed, are used for the treatment of asthma. The study, however, did not reveal the compositions of wasps' nests or indicate whether they are essentially formed by organic or inorganic compounds. The hypothesis of universal zootherapy, for example, postulates that every human culture that has developed a medical system utilizes animals as a source of medicine (Marques, 1994).

Sphecidae is an extremely diverse group of wasp species that exhibit a wide range of shapes and nesting habits, from digging nests in the soil to the construction of air nests with the use of clay or vegetable fibres (Peruquetti and Del Lama, 2003; Hook, 2004; Starr, 2004). From this perspective, the nests can contain different types of elements in their composition, from organic components, such as parts or vegetable fibre fragments or insects themselves (legs, wings or saliva), to inorganic components, such as minerals from the soil. Some studies have reported the use of insect saliva in the composition of nests, with Brian (2012) reporting on the ant Crematogaster impressa (Emery, 1899) as well as another ant species, Camponotus senex (Fr. Smith, 1858), but it is not always possible to make such claims. In the case of wasps, for example, controversial descriptions have appeared of the presence of saliva in the composition of their nests (Grandi, 1961; Pezzi, 1998; Polidori et al., 2005). The local population uses these nests mixed with olive oil to make a pasty material, which is used as an external topical medication to treat mumps and earaches. The potential of this treatment has been reported in ethnographic studies conducted by us among river-dwellers living in the Jaú (Rodrigues, 2006) and Unini (Santos et al., 2012) Rivers, which are located in the region of the Middle Negro River, Amazon, Brazil. This study aims to contribute to the list of organic, inorganic and mineral substances used in home remedies, present in wasps' nests.

\section{Materials and methods}

\section{Study area and collection of ethnopharmacological data}

The Jaú and Unini Rivers are located in the River Negro basin, Amazon, Brazil, between the municipalities of Novo Airão and Barcelos $\left(1^{\circ} 90^{\prime} \mathrm{S}\right.$ to $3^{\circ} 00^{\prime} \mathrm{S}-61^{\circ} 25^{\prime} \mathrm{W}$ to $\left.63^{\circ} 50^{\prime} \mathrm{W}\right)$, Fig. 1 . According to the Brazilian Institute of Geography and Statistics (IBGE), the area presents a tropical rainforest climate, with an average annual rainfall of $2500 \mathrm{~mm}$ and an average annual temperature of $24^{\circ} \mathrm{C}$, controlled by the action of the trade winds, equatorial low pressures, and the Intertropical Convergence Zone (ITCZ). The soils of this region, which are considered attractive sources for the building of nests, have variations in lateritic covers, classified as hydromorphic lateritic soils (FVA/IBAMA, 1998). Kaolinite and iron oxides are present in their clay fraction. The sandy fraction is composed primarily of quartz (Coelho et al., 2002; Maia and Marmos, 2010).

Ethnopharmacological surveys were conducted among the 59 expert healers of the "caboclos" river-dwellers, who live in 36 communities along the Jaú and Unini Rivers over sixteen months of fieldwork, using an ethnographic approach, as described in our previous publications (Rodrigues, 2006; Santos et al., 2012). A total of 899 homemade treatments were recorded. Many of these treatments consisted of poly-ingredients, involving interactions between plants, animals and soil origin materials.

Soil origin materials were found in only five of these treatments. Three of them contain sand, mud and a termite colony, associated with seeds of some plants - one of them was an indication of topical use for the treatment of stingray stings. The fourth treatment is for use in labour. Clay shavings are added to water, together with lemon grass roots (Cymbopogon citratus (DC.) Stapf, Poaceae), black pepper seeds (Piper nigrum L., Piperaceae) and cachaça "a distilled spirit made from sugar cane" and is ingested to increase uterine contractions at the time of birth. Finally, to treat mumps, a disease that is called "papeira" among the "caboclos" river-dwellers, a wasp nest (Sceliphron sp., Sphecidae) is crushed and mixed with olive oil to form a paste. A handful of this paste should be applied topically below the patient's ear daily until the

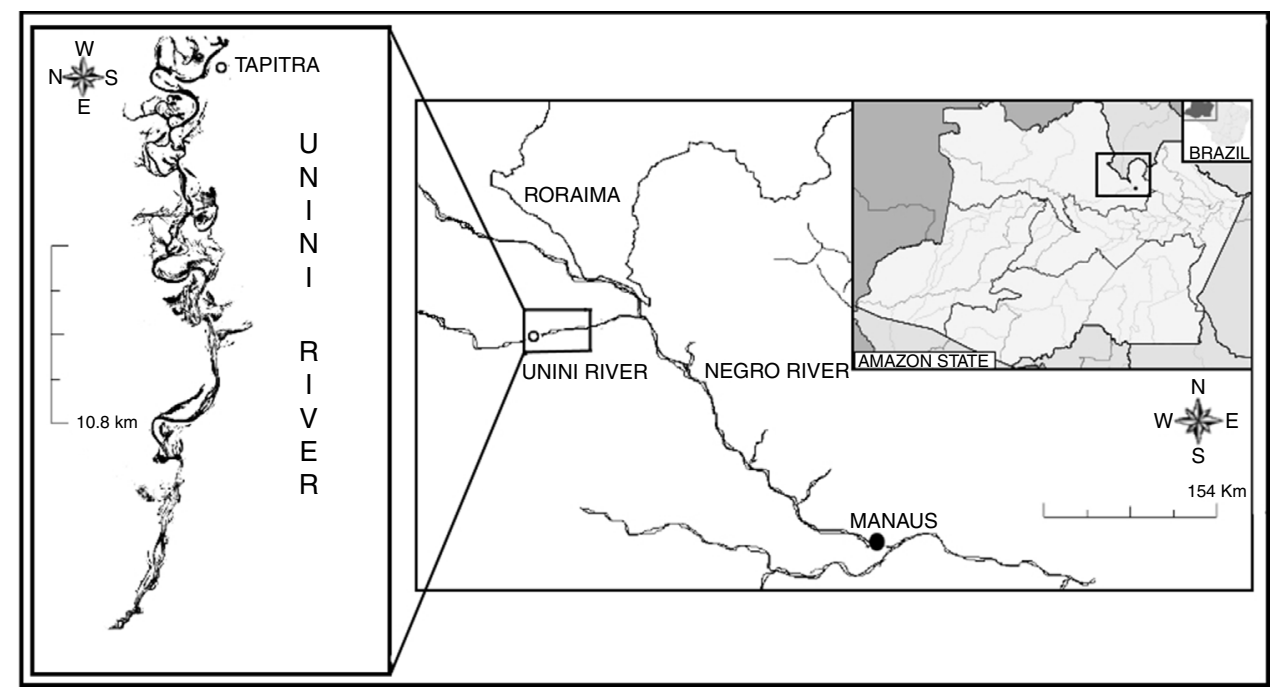

Fig. 1. The Unini and Jaú Rivers located in the River Negro basin, Amazon forest, Brazil, between the municipalities of Novo Airão and Barcelos, Tapiira Community (•). Source: Rodrigues (2006). 
symptoms disappear, i.e. inflammation shown by swelling around the neck, malaise, headache and fever.

\section{Ethics and legal aspects}

All necessary permits were obtained for the study, including a permit access to the Conservation Units, to ensure the collection of samples, the transport of biological material and access to associated traditional knowledge as well as prior informed consent of the informants (SISBIO No. 16805-2, CGEN/MMA No. 47/2009 and CEP-UNIFESP/EPM, No. 1354/08).

\section{Sample collection}

Two samples of nests of wasps, Fig. 2 indicated by the "caboclos", were collected on 11/11/2010 in the Tapiira community (located at $01^{\circ} 59^{\prime} 59.46^{\prime \prime} \mathrm{S}$ and $62^{\circ} 59^{\prime} 59.14^{\prime \prime} \mathrm{W}$ ), as shown in Fig. 1 . A soil sample was also collected from the same site as the likely source of the inorganic elements. The samples were packed in brown paper bags and labelled with the date and location. The wasps collected received the voucher number JFLS021 and were identified as Sceliphron sp., Sphecidae by the zoologist Henriques, A. L., from the National Institute for Amazonia Research (INPA). The wasps were then deposited in the collection of the Institute.

\section{Analyses of samples}

Two samples of nests (labelled CL1 and CL2), and one sample of soil (labelled S) were collected for the qualitative determination of the organic and inorganic composition by infrared spectroscopy and of the mineral composition by X-ray diffraction.

Additional quantitative data concerning the ten major chemical elements, expressed by the percentage of oxides, analyzed by X-ray fluorescence spectrometer, are also presented.

\section{Infrared spectroscopy}

Infrared spectroscopy (IR) involves the interaction of infrared radiation with matter and has been used to identify several chemical compounds, including organic and inorganic materials (solid, liquid, or gas). A typical IR spectrum can be visualized in a graph of infrared light absorbance/transmittance vs. frequency/wavelength The infrared (IR) spectra recorded to conduct this work were recorded at room temperature over the $500-4000 \mathrm{~cm}^{-1}$ range, on a Perkin Elmer FT-IR spectrophotometer (Waltham, Massachusetts, USA), equipped with a KBr beam splitter and DTGS (Detector for Fourier Transform Spectroscopy). The samples of soil (S) and nests (CL1 and CL2) were analyzed using $\mathrm{KBr}$ pellets.

\section{X-ray diffraction}

X-ray diffraction (XRD) analysis identifies minerals and mineral clay by characterizing its crystalline structure. The process results from X-ray scattering by the electrons of the crystal atoms, without wavelength change. A diffracted beam is produced by scattering when only some geometric conditions are satisfied by the Bragg law $(n \lambda=2 d \sin \theta)$, where $n$ is an integer, $\lambda$ is the wavelength, $d$ is the distance between successive parallel planes in the structure and $\theta$ is the angle of incidence and diffraction of an X-ray beam relative to a given atomic plane. The result of this type of analysis is presented in the form of a graph (diffractogram), whose variables are the angle $2 \theta$ (horizontal axis) versus the intensity of the diffracted peaks (vertical axis). The diffractogram peaks are produced when, for a given value of $\theta$, a given atomic plane has an interplanar distance $(d)$ that satisfies the Bragg law. The peak heights are proportional to the intensities of the diffraction effects. Each crystal structure produces a characteristic diffraction pattern. Therefore, to interpret the results, a database is used, and a comparison is made with the patterns produced by known and previously analyzed structures (Moore and Reynolds Jr, 1997).

To identify the clay minerals present in the soil and nests, the clay fraction of the samples was prepared using hydrogen peroxide for the removal of organic matter and using dithionitecitrate-bicarbonate for the removal of iron oxides. The following treatments were performed on the pre-treated samples to differentiate the clay minerals (i.e., expandable and non-expandable):

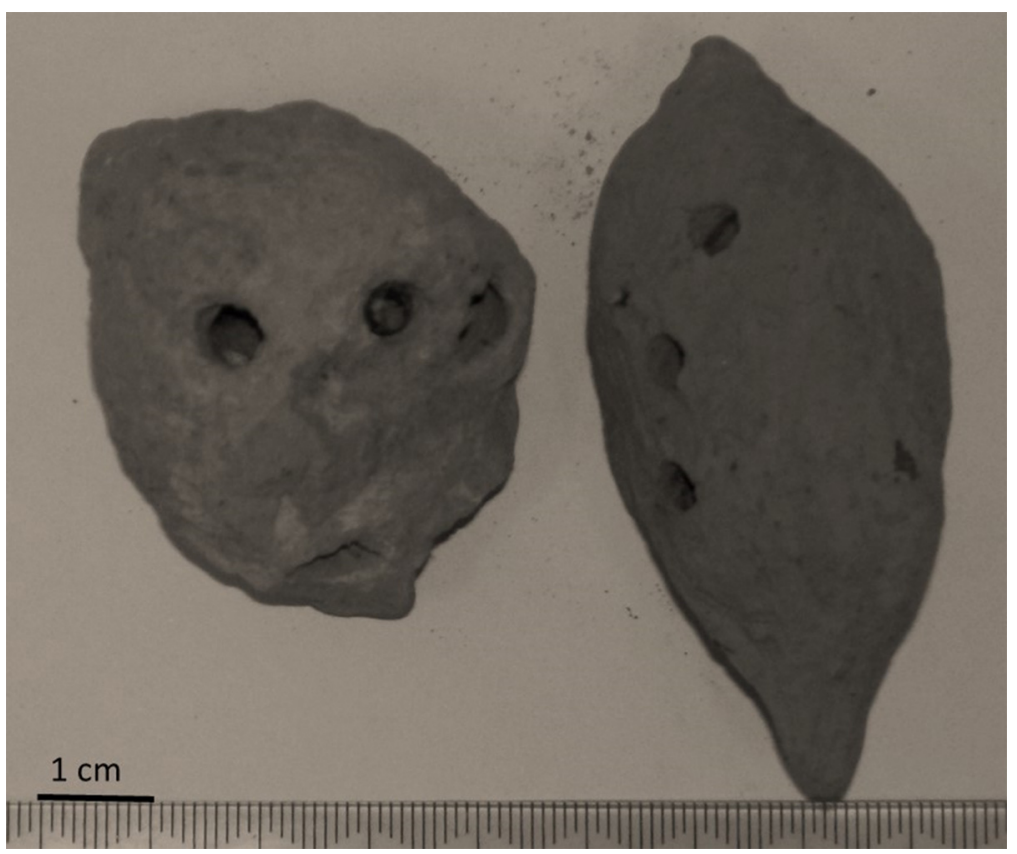

Fig. 2. The "caba-leão" wasps nests (Sceliphron sp., Sphecidae). 
saturation with $\mathrm{K}^{+}$, heating at 350 and $500^{\circ} \mathrm{C}$, saturation with $\mathrm{Mg}^{2+}$ (at $25^{\circ} \mathrm{C}$ ), and saturation with $\mathrm{Mg}^{2+}$ in an atmosphere of ethylene glycol. Thereafter, these samples were analyzed by X-ray diffraction (Miniflex II) in the Laboratory of Soil Mineralogy (Argilab-Esalq-USP). The samples were prepared on oriented blades, and the sweep amplitude used was $5-45^{\circ}\left(2 \theta^{\circ}\right)$ with $\mathrm{Cu}-\mathrm{K} \alpha$ radiation $(1.540562 \AA)$. The interpretation of diffraction was performed using the software Powder Diffraction File.

\section{X-ray fluorescence spectroscopy}

The X-ray fluorescence (XRF) is a technique which can identify and quantify the elemental composition of several solid materials using X-rays, allowing for a chemical characterization of the analyzed material and correlation with other properties (Fitton, 1997). The chemical compositions of major elements were determined by X-ray fluorescence (XRF) in the Laboratory of Technological Characterization from the Polytechnic School of the University of São Paulo. The values presented were determined in a sample fused with anhydrous lithium tetraborate in the calibration ROC-1 (Rocks), relative to the quantitative analysis comparing them with certified reference materials in an X-ray fluorescence spectrometer, PANalytical, Zetium model. The Loss on Ignition was carried out at $1020^{\circ} \mathrm{C}$ for $2 \mathrm{~h}$. The major oxides are expressed as percentage by weight (wt\%).

\section{Results}

The infrared spectrum of the soil sample (S) is shown in Fig. 3. Strong bands at 3436 and $1027 \mathrm{~cm}^{-1}$, corresponding to $\mathrm{O}-\mathrm{H}$ stretching and $\mathrm{Si}-\mathrm{O}-\mathrm{Si}$ fundamental vibrations, respectively, were observed. These data, associated to the presence of a weaker $\mathrm{O}-\mathrm{H}$ bending vibration at $1636 \mathrm{~cm}^{-1}$, indicated the presence of
Table 1

Major-element contents of the nests of "Caba-Leão" wasps studied.

\begin{tabular}{lcc}
\hline Oxides (wt.\%) & $\begin{array}{l}\text { Nests of “Caba-leão 1" } \\
\text { (CL1) }\end{array}$ & $\begin{array}{l}\text { Nests of “Caba-leão 2" } \\
\text { (CL2) }\end{array}$ \\
\hline $\mathrm{SiO}_{2}$ & 84.4 & 76.7 \\
$\mathrm{Al}_{2} \mathrm{O}_{3}$ & 8.09 & 7.91 \\
$\mathrm{Fe}_{2} \mathrm{O}_{3}$ & 1.23 & 3.26 \\
$\mathrm{MnO}$ & $<0.10$ & $<0.10$ \\
$\mathrm{MgO}$ & 0.12 & $<0.10$ \\
$\mathrm{CaO}$ & $<0.10$ & $<0.10$ \\
$\mathrm{Na}$ & $<0.10$ & $<0.10$ \\
$\mathrm{~K}_{2} \mathrm{O}$ & 0.47 & 0.22 \\
$\mathrm{TiO}_{2}$ & 0.94 & 1.27 \\
$\mathrm{P}_{2} \mathrm{O}_{5}$ & 0.10 & 0.14 \\
$\mathrm{LOI}$ & 4.16 & 9.67 \\
\hline
\end{tabular}

LOI, loss on ignition.

silicate material (Athawale and Kulkarni, 2011). Otherwise, the IR spectra of nests (CL1) and (CL2) (Fig. 2) showed, in addition to the bands assigned to silicate material, broad intense peaks of approximately $3412 \mathrm{~cm}^{-1}$, characteristic of hydroxyl groups, as well as weak symmetrical and asymmetrical stretching peaks near 1600 and $1400 \mathrm{~cm}^{-1}$, respectively, characteristic of carboxyl groups (Khondkar, 2009).

The mineralogy of the soil (S) and nests (CL1 and CL2) are indicated by the X-ray diffractograms in Fig. 4. The analysis of the diffraction peaks indicate the minerals quartz $\left(\mathrm{SiO}_{2}\right)$, kaolinite $\left(\mathrm{Al}_{2} \mathrm{Si}_{2} \mathrm{O}_{5}(\mathrm{OH})_{4}\right)$, illite $\left(\mathrm{K}, \mathrm{H}_{3} \mathrm{O}\right)(\mathrm{Al}, \mathrm{Mg}, \mathrm{Fe})_{2}(\mathrm{Si}, \mathrm{Al})_{4} \mathrm{O}_{10}\left[(\mathrm{OH})_{2}, \mathrm{H}_{2} \mathrm{O}\right]$ and gibbsite $\mathrm{Al}(\mathrm{OH})_{3}$. The results of X-ray analysis of wasp nests samples revealed that the silicates were quartz, kaolinite and illite, confirming the results obtained by infrared spectroscopy. The $\mathrm{X}$-ray diffractograms also indicated that the main source of the minerals present in wasp nests came from the soil.
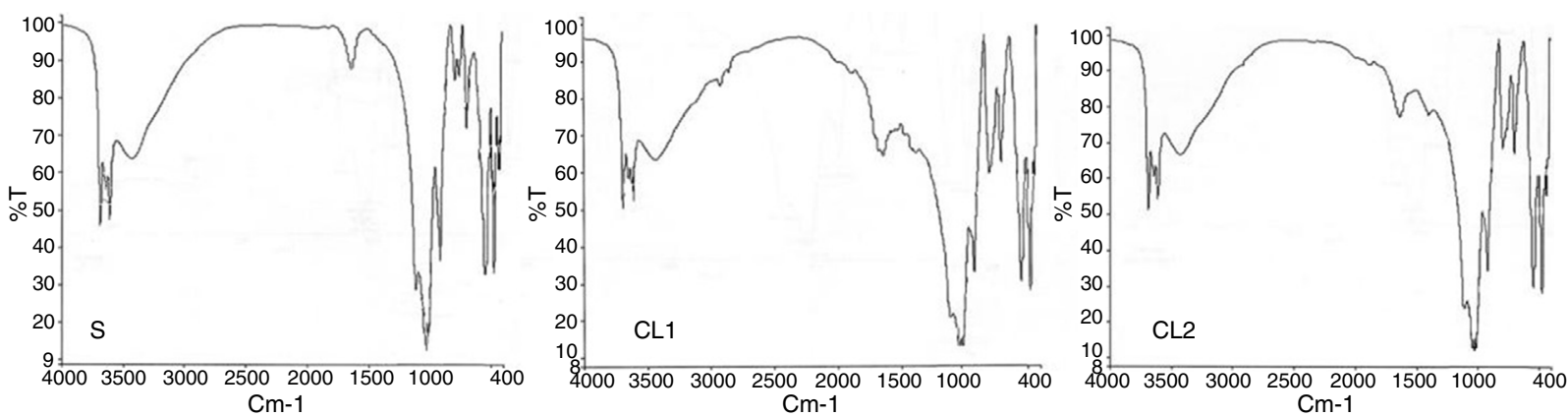

Fig. 3. IR spectra of analyzed materials in KBr pellets. Samples: (S), soil; (CL1 and CL2), "caba-leão" wasps nests.

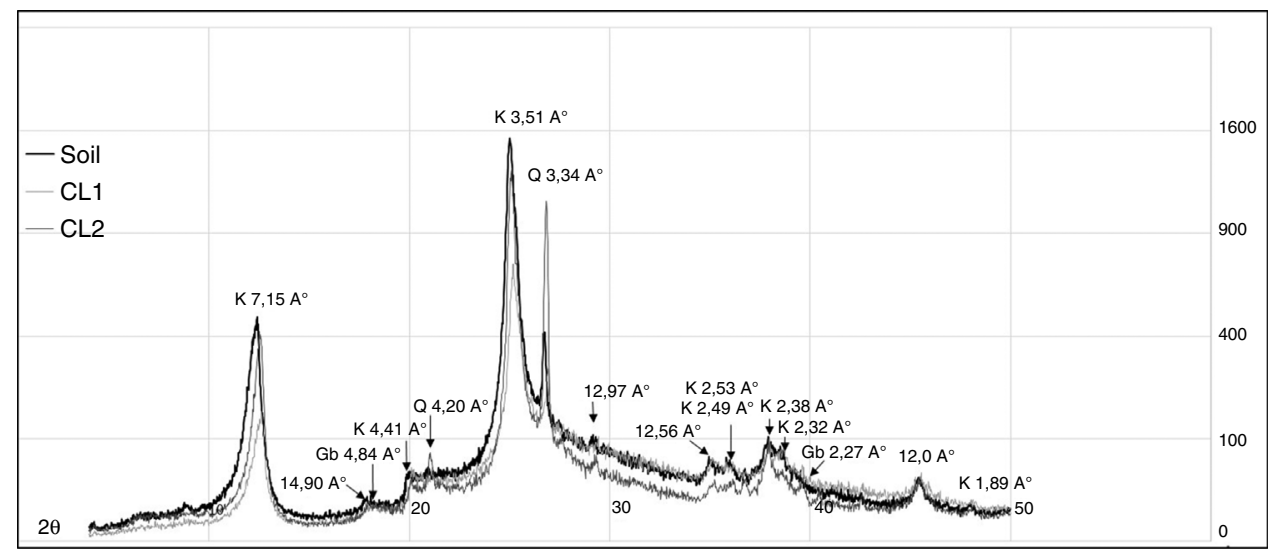

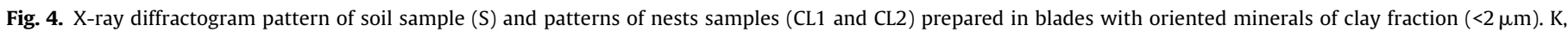
kaolinite $\mathrm{Al}_{2} \mathrm{Si}_{2} \mathrm{O}_{5}(\mathrm{OH})_{4}$; Q, quartz $\left(\mathrm{SiO}_{2}\right)$; I, illite $\left(\mathrm{K}, \mathrm{H}_{3} \mathrm{O}\right)(\mathrm{Al}, \mathrm{Mg}, \mathrm{Fe})_{2}(\mathrm{Si}, \mathrm{Al})_{4} \mathrm{O}_{10}\left[(\mathrm{OH})_{2}, \mathrm{H}_{2} \mathrm{O}\right]$; $\mathrm{Gb}$, gibbsite $\mathrm{Al}(\mathrm{OH})_{3}$. 
Table 1 presents the ten major chemical elements of the wasps nests by X-ray fluorescence spectrometer. Silica is the most abundant major oxide, followed by the oxides of aluminium and iron. The chemical elements composing the nests were derived mainly from the minerals quartz $\left(\mathrm{SiO}_{2}\right)$, kaolinite $\left(\mathrm{Al}_{2} \mathrm{Si}_{2} \mathrm{O}_{5}(\mathrm{OH})_{4}\right)$, illite $\left(\mathrm{K}, \mathrm{H}_{3} \mathrm{O}\right)(\mathrm{Al}, \mathrm{Mg}, \mathrm{Fe})_{2}(\mathrm{Si}, \mathrm{Al})_{4} \mathrm{O}_{10}\left[(\mathrm{OH})_{2}, \mathrm{H}_{2} \mathrm{O}\right]$ and gibbsite $\mathrm{Al}(\mathrm{OH})_{3}$. Iron may also be present as impurities in minerals such as quartz or as an amorphous element in the soil and in wasps nests. Other oxides of major elements are found in trace quantities. Loss on ignition shows a significant loss of volatile elements, between 4 and 9 (wt\%).

\section{Discussion}

Wild and domestic animals and their products and by-products such as hooves, skins, bones, feathers, prey, body secretions and excrement, or materials such as cocoons and nests are important ingredients to prepare preventive, protective and curative medicine (Adeola, 1992; Unnikrishnan, 1998). In our fieldwork, the nests were mixed with another ingredient, which was olive oil, obtained from the plant Olea europaea L., Oleaceae. According to Eidi et al. (2012), olive oil also has antinociceptive and antiinflammatory effects in mice. The antinociceptive effects of the oil were studied using formalin, a hot plate and writhing tests in mice, while its acute anti-inflammatory effects were studied using the xylene ear oedema test. Olive oil (1, 5 and $10 \mathrm{ml} / \mathrm{kg}$ body wt.) was injected intraperitoneally. Other authors have also observed such effects during pharmacological trials (Bitler et al., 2005; EsmaeiliMahani et al., 2010; Süntar et al., 2010). Moreover, from the topical point of view, two studies demonstrate anti-inflammatory effects of this oil. Thus, Cui et al. (2015) evaluated that olive oil significantly decreased the intensity of acute dermatitis in patients with nasopharyngeal carcinoma (NPC) when submitted to chemoradiotherapy. De la Puerta et al. (2000) found anti-inflammatory effects of olive oil when applied topically, inhibiting the prostanoid production and neutrophil influx which might contribute to the potential biological properties reported for this oil. These data reinforced the statements made by the practitioners of local folk medicine regarding the treatment of mumps and ear pain.

The analyses showed that the soils of the region are the main attractive source for the wasps to build their nests, and the mineralogical and chemical properties are present in the pasty material that is used as a homemade medicine for the treatment of mumps and ear pain. Costa-Neto (2002) reported the use of insects and their products in folk medicine in Northeastern Brazil, and some therapeutic use was recorded for the mud wasp ("marimbondode-barro" or "caçador", Sphecidae) among Pankararé Indians and in rural communities; the same use recorded by us among the "caboclos" from Unini and Jaú River. These cultures in general melted the nests in water and/or oils and applied the mixture to the mumps; in which minerals could be present.

Although it is difficult to obtain lists of minerals and clay minerals used in therapeutic treatments from the literature, Williams and Haydel (2010) comment on the traditional uses of clay, mud and soils in traditional medicine for different applications, citing examples of treatments and healing for ulcers, tumours, cysts, cancers, osteoporosis and others.

The multifaceted role of clay minerals in pharmaceuticals is presented by Khurana et al. (2015). The authors include a summary of the pharmacological activities of some clay minerals, such as kaolinite, talc, palygorskite and smectites, which are used for therapeutic purposes in pharmaceutical formulations as active principles or excipients used in paste to treat mumps

Additionally, Carretero (2002) indicated the therapeutic actions of clay regarding its antiseptic, analgesic, detoxifying, mineralizing, thermal, and energy balancing, anti-inflammatory, antibacterial and healing properties. However, there is a lack of information in the literature about the types of clays present in therapeutic treatments, including clay minerals and their chemical components.

Mumps is an infectious, contagious disease that affects the salivary glands located near the ears. The treatment of mumps aims to only relieve symptoms using analgesics and antipyretics because the body itself is responsible for fighting the infection by forming specific antibodies against the virus that causes the disease. In this regard, according to the therapeutic uses mentioned in the Manual of Applied Geotherapy (2000), the use of this home remedy is justified for both mumps and earaches, as indicated in local medicine.

\section{Conclusion}

This research contributes to the study of substances present in homemade remedies used by the riverine communities of the Amazon, especially emphasizing the presence of minerals in the composition of homemade paste to treat mumps. kaolinite presents the main chemical components ( $\mathrm{Si}$ and $\mathrm{Al}$ ) investigated in wasps nests, in addition to quartz and illite mica. All these components, added to the olive oil, form the paste manipulated by the "cablocos" for topic use. According to Khurana et al. (2015), kaolinite has anti-inflammatory properties and adheres to the skin, forms a protective film and absorbs secretions, promoting a gentle antiseptic action.

Finally, new studies should be improved to contribute to the applications and uses of minerals in traditional medicine in order to also try to establish possible connections with pharmaceutical properties. This research contributed to the study of substances found in homemade remedies used by the riverine communities of the Amazon, which are the result of insect-mineral-vegetable oil-interaction.

\section{Authors' contributions}

ER and JS contributed to field research and sample collection. JL contributed to the analysis of IR spectra. ALVB contributes to the analysis of X-ray diffraction and the X-ray Fluorescence and interpretation of the results. In addition, she organized the manuscript. All the authors have read the final manuscript and approved the submission.

\section{Ethical disclosures}

Protection of human and animal subjects. The authors declare that for this research there will be no experiments on human beings and/or animals.

Confidentiality of data. The authors declare that no patient data appear in this article.

Right to privacy and informed consent. The authors declare that no patient data appear in this article.

\section{Conflicts of interest}

The authors declare no conflicts of interest.

\section{Acknowledgments}

The authors thank the inhabitants of the Jaú and Unini River for their contributions to this work. We thank CAPES and CNPq for granting the doctoral fellowships and FAPESP/Biota 09/533822 for making the field work possible. We also thank the Vitoria 
Amazônica Foundation, the Unini River Extractive Reserve and Jaú National Park for providing the initial contacts with the community and the logistical support. We would like to acknowledge the expert Henriques, A.L. at the INPA Zoological Collection for assistance with the taxonomical identification of Sceliphrons sp. Sphecidae, Juliana de Faria Lima Santos for collecting the samples and Dario Santos for your comments and help.

\section{References}

Adeola, M.O., 1992. Importance of wild animals and their parts in the culture, religious festivals, and traditional medicine, of Nigeria. Environ. Conserv. 19, $125-134$

Alves, R.R.N., Rosa, I.L., 2013. Animals in Traditional Folk Medicine: Implications for Conservation. Springer, Berlin/New York

Anageletti, L.R., Agrimi, U., Curia, C., French, D., Mariani-Costantini, R., 1992. Healing rituals and sacred serpents. Lancet 340, 223-225.

Antonio, R.L., Kozasa, E.H., Galduróz, J.C.F., Dawa Dorjee, Y., Kalsang, T., Norbu, T., Tenzin, T., Rodrigues, E., 2013. Formulas used by Tibetan doctors at Men-Tsee-Khang in India for the treatment of neuropsychiatric disorders and their correlation with pharmacological data. Phytother. Res. 27, 552-563.

Athawale, V.D., Kulkarni, M.A., 2011. Synthesis and performance evaluation of polyurethane/silica hybrid resins. Pigm. Resin. Technol. 40, 49-57.

Bitler, C.M., Viale, T.M., Damaj, B., Crea, R., 2005. Hydrolyzed olive vegetation water in mice has anti-inflammatory activity. J. Nutr. 135, 1475-1479.

Brian, M.V., 2012. Social Insects: Ecology and Behavioural Biology. Springer Science \& Business Media, Berlim.

Calderon Espina, L.E., 1989. Uso de miel de abeja en heridas operatorias dehiscentes en pacientes post-cirurgı obstetricas. Faculdade de Ciências Médicas da Universidade de San Carlos de Guatemala, Guatemala, 47 p.

Carretero, M.I., 2002. Clay minerals and their beneficial effects upon human health. A review. Appl. Clay. Sci. 21, 155-163.

Cheesman, O.D., Brown, V.K., 1999. Conservation of the wart biter bush cricketflagship or pharmaceutical? Antenna 23, 70-75.

Coelho, M.R., Santos, H.G., Silva, H.F., Agilo, M.L.D., 2002. O recurso natural solo. In Manzatto, C.V., Junior, E.F., Peres, J.R.R. (Eds.), Uso agrícola dos solos brasileiros. Embrapa Solos, Rio de Janeiro, pp. 1-11.

Costa-Neto, E.M., 2002. The use of insects in folk medicine in the state of Bahia, northeastern Brazil, with notes on insects reported elsewhere in Brazilian folk medicine. Hum. Ecol. 30, 245-263.

Cui, Z., Xin, M., Yin, H., Zhang, J., Han, F., 2015. Topical use of olive oil preparation to prevent radiodermatitis: results of a prospective study in nasopharyngeal carcinoma patients. Int. J. Clin. Exp. Med. 8, 11000-11006.

De la Puerta, R., Martinez-Dominguez, E., Ruiz-Gutierrez, V., 2000. Effect of minor components of virgin olive oil on topical antiinflammatory assays. Z. Naturforsch. C 55, 814-819.

Eidi, A., Moghadam-kia, S., Moghadam, J.Z., Eidi, M., Rezazadeh, S., 2012. Antinociceptive and anti-inflammatory effects of olive oil (Olea europeae L.) in mice. Pharm. Biol. 50, 332-337.

Esmaeili-Mahani, S., Rezaeezadeh-Roukerd, M., Esmaeilpour, K., Abbasnejad, M. Rasoulian, B., Sheibani, V., Hajializadeh, Z., 2010. Olive (Olea europaea L.) leaf extract elicits antinociceptive activity, potentiates morphine analgesia and suppresses morphine hyperalgesia in rats. J. Ethnopharmacol. 132, 200-205.

Fernandes-Silva, C.C., Salatino, M.L.F., Teixeira, E.W., Salatino, A., 2014. Planta Med. $80,1514-1514$

FVA/IBAMA, 1998. Plano de Manejo do Parque Nacional do Jaú. Fundação Vitória Amazônica, Manaus, http://www.icmbio.gov.br/portal/images/stories/ docs-planos-de-manejo/parna_jau_pm.pdf (accessed 23.07.16).

Grandi, G., 1961. Studi di un entomólogo sugli imenotteri superiori. Edizioni Calderini, Bologna

Fitton, G., 1997. X-Ray fluorescence spectrometry. In: Gill, R. (Ed.), Modern Analytical Geochemistry: An Introduction to Quantitative Chemical Analysis for Earth, Environmental and Material Scientists. Addison Wesley Longman, UK.

Harvey, A.L., 2008. Natural products in drug discovery. Drug Discov. Today 13, 894-901.

Hook, A.W., 2004. Nesting behavior of Chlorion cyaneum (Hymenoptera: Sphecidae) a predator of cockroaches (Blattaria: Polyphagidae). J. Kans. Entomol. Soc. 77 $558-564$.
Khurana, I.S., Kaur, S., Kaur, H., Khurana, R.K., 2015. Multifaceted Role of Clay Minerals in Pharmaceuticals Future Sci. OA, https://www.future-science.com/ doi/pdf/10.4155/fso.15.6 (accessed 05.01.18).

Khondkar, P., 2009. Composition and partial structure characterizations of Tremella polysaccharides. Mycobiology 37, 286-294.

Kujundžić, N., Glibota, M., Škrobonja, A., Gašparac, P., 2008. Manuscript containing a collection of medical recipes written in 1776 by a catholic priest Petar KašTelan of Croatia (Review). Acta. Med. Hist. Adriat. 6, 15-40.

Lev, E., Amar, Z., 2000. Ethnopharmacological survey of traditional drugs sold in Israel at the end of the 20th century. J. Ethnopharmacol. 72, 191-205.

Lev, E., 2003. Traditional healing with animals (zootherapy): medieval to presentday Levantine practice. J. Ethnopharmacol. 86, 107-118.

Lopez, B.G.C., De Lourenço, C.C., Alves, D.A., Machado, D., Lancellotti, M., Sawaya, A.C.H.F., 2015. Antimicrobial and cytotoxic activity of red propolis: an alert for its safe use. J. Appl. Microbiol. 119, 677-687.

Liu, W., Zhou, G., Li, G., Min, D., 2011. Research of origin and ethnopharmacological uses of mineral medicine Halitum. Zhongguo Zhong. Yao. Za. Zhi. 36, 2445-2449.

Maia, M.A.M., Marmos, J.L., 2010. Geodiversidade do Estado do Amazonas. Ministério de Minas e Energia. Secretaria de Geologia. In: Mineração e Transformação Mineral CPRM. Serviço Geológico do Brasil, Brasília.

Manual of Applied Geotherapy, 2000. Organización Panamericana de la Salud. Organización Mundial de la Salud. Programa Nacional de Medicina Complementária, Peru, http://www.bvsde.paho.org/texcom/manualesMEC geoterapia/geoterapia.html (accessed 22.06.16).

Marques, J.G.W., 1994. A fauna medicinal dos índios Kuna de San Blas (Panamá) e a hipótese da universalidade zooterápica. In: Anais 46th Reunião Anual da Sociedade Brasileira para o Progresso da Ciência, Vitória, ES, Brasil.

Mati, E., de Boer, H., 2011. Ethnobotany and trade of medicinal plants in the Qaysari Market, Kurdish Autonomous Region. Iraq. J. Ethnopharmacol. 133, 490-510.

Mayer, A.M.S., Gustafson, K.R., 2003. Marine pharmacology in 2000: antitumor and cytotoxic compounds. Int. J. Cancer 105, 291-299.

Moore, D.M., Reynolds Jr., R.C., 1997. X-ray Diffraction and the Identification and Analysis of Clay Minerals. Oxford University Press, New York.

Peruquetti, R.C., Del Lama, M.A., 2003. Notas sobre a socialidade e a biologia de nidificação Trypoxylon (Trypoxylon) asuncicola Strand, (Hymonoptera Sphecidade). Rev. Bras. Entomol. 47, 581-588.

Pezzi, G., 1998. Observations on the biology of Sceliphron spirifex (Linnaeus, 1758) in Romagna (Inserta Hymenoptera, Sphecidae). Quad. Stud. Not. Stor. Nat. Romagna. 10, 71-75.

Pieroni, A., Quave, C., Nebel, S., Heinrich, M., 2002. Ethnopharmacy of the ethnic Albanians (Arbëreshë) of northern Basilicata, Italy. Fitoterapia 73, 217-241.

Pieroni, A., Muenz, H., Akbulut, M., Başer, K.H., Durmuşkahya, C., 2005. Traditional phytotherapy and trans-cultural pharmacy among Turkish migrants living in Cologne, Germany. J. Ethnopharmacol. 31, 69-88.

Polidori, C., Trombino, L., Fumagalli, C., Andrietti, F., 2005. The nest of the muddauber wasp, Sceliphron spirifex (Hymenoptera Sphecidae): application of geological methods to structure and brood cell contents analysis. Ital. J. Zool. 72, 153-159.

Rigat, M., Vallès, J., Iglésias, J., Garnatje, T., 2013. Traditional and alternative natural therapeutic products used in the treatment of respiratory tract infectious diseases in the eastern Catalan Pyrenees (Iberian Peninsula). J. Ethnopharmacol. $148,411-422$

Ritter, R.A., Monteiro, M.V., Monteiro, F.O., Rodrigues, S.T., Soares, M.L., Silva, J.C., Palha, M., Biondi, G.F., Rahal, S.C., Tourinho, M.M., 2012. Ethnoveterinary knowledge and practices at Colares Island, Pará state, eastern Amazon, Brazil. J. Ethnopharmacol. 144, 346-352.

Rodrigues, E., 2006. Ethnopharmacology in the Jaú National Park (JNP), state of Amazonas, Brazil. Phytother. Res. 20, 378-391.

Santos, J.F.L., Pagani, E., Ramos, J., Rodrigues, E., 2012. Observations on the therapeutic practices of riverine communities of the Unini River, AM, Brazil. J. Ethnopharmacol. 142, 503-515.

Starr, C.K., 2004. Nesting biology of the solitary wasp Pison argentatum (Hymenoptera: Sphecidae) in Borneo and the Philippines. J. Kans. Entomol. Soc. 77, 565-572.

Süntar, I.P., Akkol, E.K., Baykal, T., 2010. Assessment of anti-inflammatory and antinociceptive activities of Olea europaea L. J. Med. Food 13, 352-356.

Unnikrishnan, P.M., 1998. Animals in ayurveda. Amruth 1, 1-23.

Williams, L.B., Haydel, S.E., 2010. Evaluation of the medicinal use of clay minerals as antibacterial agents. Int. Geol. Rev. 52, 745-770. 